\title{
Transformation of Location Permit Services through Electronic System
}

\author{
Ima Mayasari ${ }^{1}$ \\ imamayasari@ui.ac.id ${ }^{1}$ \\ Faculty of Administrative Science Universitas Indonesia ${ }^{1}$
}

\begin{abstract}
The location permit transformation after the implementation of Online Single Submission (OSS), has changed in governance. Current Location Permits are not granted manually but through an online system based on the Regulation of the Minister of Agrarian Affairs and Spatial Planning/Head of the National Land Agency (ATR/BPN) Number 14 of 2018 on Location Permits. This research is focused on analyzing the policy of transformation of location permit services after the implementation of OSS both retrospectively (ex-post) to see what is happening, and what is the difference with previous arrangements and prospective (ex-ante) to see what will happen and what should be done. The research method uses the normative juridical method. The results showed that there were differences in the authority to grant location permits, which were previously issued by Regents/Mayors, Governors, and Ministers in accordance with their authority to be issued by OSS Institutions based on Commitment of Business Actors (expost) while prospective (ex-ante) matters encourage the acceleration of business licensing, and synchronize spatial planning and spatial use, supported by One Map Policy and One Data Indonesia
\end{abstract}

Keywords: location permit, policy analysis, online single submission.

\section{Introduction}

The implementation of business licensing through Online Single Submission (OSS), as regulated in Government Regulation Number 24 of 2018 on Electronic Integrated Business Licensing Service (GR No. 24/2018) that has changed the business process in granting Location Permits. So far there have been many problems in grating location permits, especially the issue of overlapping location permit and issuance of location permits in a manner that is not in accordance with statutory provisions.

This location permit is also a determining factor for businesses to start businesses in Indonesia. After the business actor has obtained investment approval from the Investment Coordinating Board (BKPM), the land required by the business actor to conduct business is required to have a location permit. The definition of Location Permit according to Article 1 number 1 of the Regulation of the Minister of ATR/BPN Number 19 of 2017 on Amendment to the Regulation of the Minister of ATR/BPN Number 5 of 2015 on Location Permit is a permit granted to a company to obtain land needed in the context of an applicable investment as a permit to transfer rights, and to use the land for capital investment. The definition implies that every company that has obtained an investment approval must have a location permit to obtain the land needed to carry out the capital investment that is carried out.

Companies that are applying for location permits are prohibited from carrying out land acquisition activities before the location permit is determined. However, there are exceptions 
in granting location permits, where location permits are not required and are deemed already owned by the company concerned in terms of (a) the land to be obtained is income (inbreng) from the shareholders; (b) the land to be obtained is land which is already controlled by another company in the context of continuing the implementation of part or all of the capital investment of other companies, and for that the approval of the authorized agency has been obtained; (c) land to be acquired is needed in the context of carrying out industrial business in an industrial area; (d) the land to be obtained comes from the authority or the organizer of the development of an area in accordance with the spatial plan of the development area; (e) land to be acquired is needed for business expansion that is already in progress and for that expansion a business expansion permit has been obtained in accordance with applicable regulations, whereas the location of the land is bordered by the location of the business concerned; (f) land required to carry out a capital investment is not more than: (1) 25 hectares (twenty five hectares) for agricultural business; (2) 10,000 $\mathrm{m} 2$ (ten thousand square meters) for non-agricultural businesses; and (3) $50,000 \mathrm{~m} 2$ (fifty thousand square meters) for the construction of houses for the MBR; (g) land that will be used to carry out the capital investment is land that is already owned by the company concerned through the transfer of rights from another company, provided that the land is located in a location according to the applicable Regional Spatial Plan intended for use in accordance with the capital investment.

With the OSS system, starting from the authority, procedure, and substance of the Location Permit has changed, which is faster in terms of time, easier procedures, and low cost. OSS has become one of the achievements in reforming the business licensing business process - using the transformation of technological advancements - including relating to location permits. The speed of time in granting business permits, one of which is constrained by the problem of location permits.

Location permits are important to be improved in governance. One indicator that assesses Indonesia's competitiveness is the ease of investment. An important step that needs to be taken to ease of doing business is to reform regulations relating to investment or business in Indonesia. Regulatory reform is one of the important agendas that Indonesia needs to undertake, to improve the quality of regulations (high-quality regulations).

The Indonesian government has succeeded in realizing regulatory reform in facilitating economic development. Regulatory reform has begun since the monetary crisis that struck Indonesia in 1998 and was started by the government in the reform era. Previously, in 1995, the Organization for Economic Co-operation and Development (OECD) Council asked its member countries to improve the quality of regulations [1].

Various steps have been taken to make improvements to regulations in Indonesia, but these steps have encountered obstacles in terms of one conflicting legislation and other legislation conflicting. The disharmony of regulations occurs because the egos of each sector produce regulations that are not aligned with the laws and regulations of other sectors.

In the investment sector, each sector has arrangements for licensing mechanisms in the investment sector that are opened in Indonesia. Business licenses issued by ministries or agencies and local governments to start, implement and develop business activities, face problems related to their implementation. Restructuring regulations that support the acceleration of implementation is important, to reduce barriers to developing business activities.

The Ease of Doing Business ranking in 2019, Indonesia ranked 73 (seventy-three) in the Ease of Doing Business Rank [20]. While ranking in Starting a Business, Indonesia ranks 134 (one hundred thirty-four). Compared to allied countries, Indonesia is still below those 
countries as shown in Table 1. Ranking and Ease of Doing Business Rank of Allied Countries, as follows: [2]

Table 1. Ranking and Ease of Doing Business Value for Allied Countries

\begin{tabular}{|c|c|c|}
\hline Economy & $\begin{array}{c}\text { Ease of Doing } \\
\text { Business Rank }\end{array}$ & Starting a Business \\
\hline Singapore & 2 & 3 \\
\hline Malaysia & 15 & 122 \\
\hline Thailand & 27 & 39 \\
\hline $\begin{array}{c}\text { Brunei } \\
\text { Darussalam }\end{array}$ & 55 & 16 \\
\hline Vietnam & 69 & 104 \\
\hline Indonesia & 73 & 134 \\
\hline
\end{tabular}

Source: https://www.doingbusiness.org/en/rankings.

Table 1. above suggests that the ranking of business ease and starting a business in Indonesia is still below the allied countries such as Singapore, Malaysia, Thailand, Brunei Darussalam, and Vietnam. In this case, the economy is given a ranking based on ease of doing business, from 1-190 [2]. Ease of doing business means the regulatory environment is more conducive to starting and operating a company. The ranking is determined by sorting aggregate scores on 10 (ten) topics, each consisting of several indicators that give equal weight to each topic. The ranking of the whole country refers to May 2018 [2].

Ease of doing business helps assess the absolute level of regulatory performance over time. This illustrates the gap in each economy from the best regulatory performance observed in each indicator in all economies in the Doing Business example since 2005. Thus it can be seen the gap between certain economic performance and the best performance at each time point and assess absolute changes in the economic regulatory environment over time as measured by Doing Business [2].

In order to follow up on the provisions of Article 32 paragraph (2) letter a and Article 43 paragraph (1) GR No. 24/2018, and to encourage economic growth and increase investment in industrial estates, it is deemed necessary to make adjustments location permit services as stipulated in the Regulation of the Minister of Agrarian Affairs and Spatial Planning/Head of the National Land Agency Number 5 of 2015 on Location Permits, as amended by Regulation of the Minister of Agrarian Affairs and Spatial Planning/Head of the National Land Agency Number 19 of 2017 on Amendments to the Regulation of the Minister of Agrarian Affairs and Spatial Planning/Head of National Land Agency Number 5 of 2015 on Location Permit.

In addition to location permits, adjustments to the technical considerations of land regulations are also regulated in the National Land Agency Head Regulation No. 2 of 2011 on Guidelines for Land Technical Considerations in Issuance of Location Permits, Location Determination, and Land Use Change Permits, and Head of National Land Agency Regulation Number 1 of 2010 on Standards for Regulation and Services of Land Affairs, and Regulation of the Minister of Agrarian Affairs and Spatial Planning / Head of National Land Agency Number 4 of 2017 on Service Standards of the Ministry of Agrarian Affairs and Spatial Planning / National Land Agency.

On July 13, 2018, two Regulations of the Minister of Agrarian Affairs and Spatial Planning/Head of the National Land Agency responded to the implementation of the Online Single Submission (OSS). Two ATR /BPN Ministerial Regulations issued, namely (1) Regulation of the Minister of Agrarian Affairs and Spatial Planning/Head of National Land Agency Number 14 of 2018 on Location Permit; and (2) Regulation of the Minister of 
Agrarian Affairs and Spatial Planning/Head of National Land Agency Number 15 of 2018 on Technical Considerations on Land.

The statutory regulations which form the legal basis for the issuance of ATR / BPR Ministerial Regulation Number 14 of 2018 include: Law Number 5 of 1960 on Basic Agrarian Regulations, Law Number 25 of 2007 on Investment, Law Number 26 of 2007 on Spatial Planning, Law Number 18 of 2012 on Food, Law Number 3 of 2014 on Industry, Law Number 23 of 2014 on Regional Government.

Meanwhile, there are also Government Regulations that become the basis for issuance, including Government Regulation Number 16 of 2004 on Land Use, Government Regulation Number 15 of 2010 on Spatial Planning, Government Regulation Number 64 of 2016 on Development of Low-Income Community Housing, Government Regulation Number 24 of 2018 on Electronically Integrated Business Licensing Services. Furthermore, there is also the Regulation of the Head of the National Land Agency Number 1 of 2010 on Service Standards and Regulation of Land Affairs, Regulation of the Minister of Agrarian Affairs and Spatial Planning / Head of the National Land Agency Number 17 of 2016 on Land Management in Coastal Areas and Small Islands, Regulation of the Minister of Agrarian Affairs and Spatial Planning / Head of National Land Agency Number 4 of 2017 on Ministry of Agrarian Service Standards and Spatial Planning / Head of National Land Agency.

Transforming technological progress, making Indonesia enter the era of disruption (disruption era), where innovation is very important. The development of this technology also influences the legislation governing business licensing in Indonesia. In evaluating the location permit policy issues after the application of the licensing service seeks to be integrated electronically, the policy analysis used uses the Policy Analysis Theory put forward by William N. Dunn. [3] Two things that William N. Dunn saw in conducting a policy analysis were retrospective (ex-post) to see what was happening, and how it was different from previous arrangements and prospective (ex-ante) to see what would happen and what had to be done [3].

Figure 1. Form of Policy Analysis 


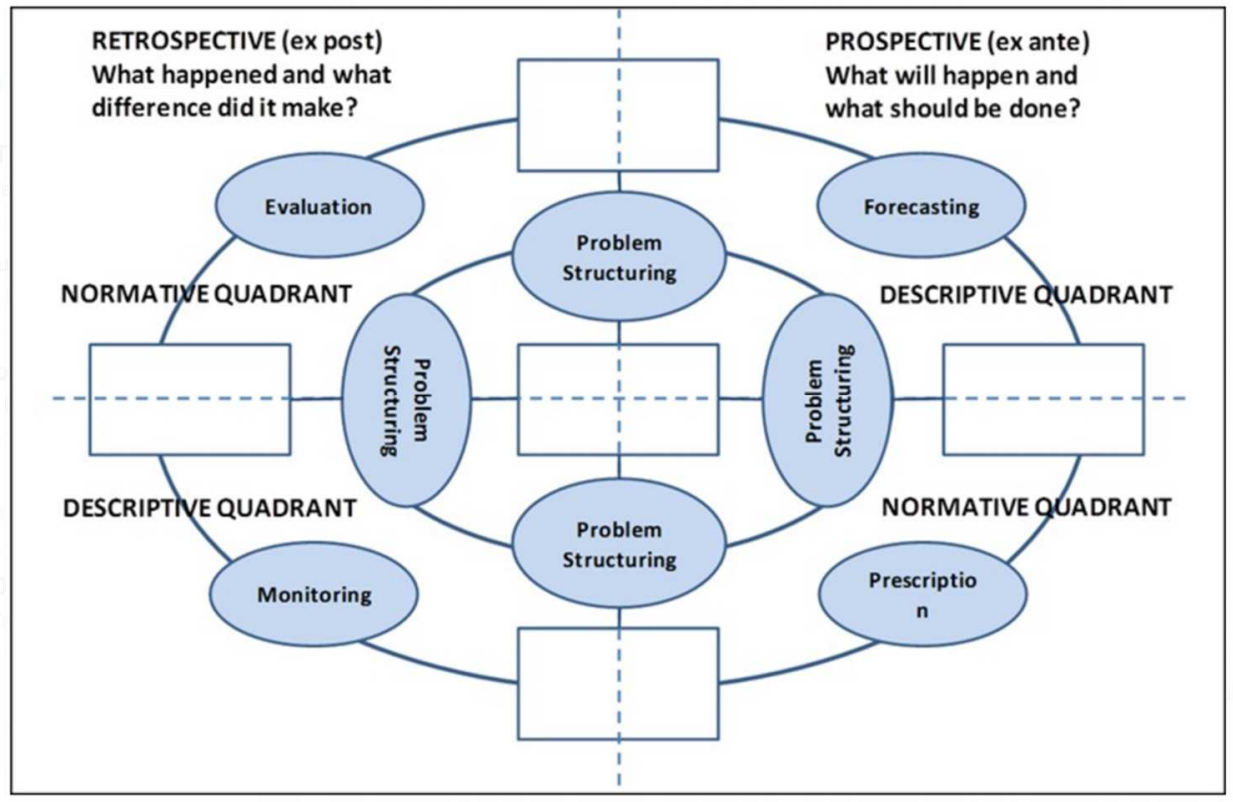


Source: William N. Dunn, Public Policy Analysis An Integrated Approach, 2018.

Prospective policy analysis involves the production and transformation of knowledge before a prescription is made. Prospective, or ex-ante analysis, signifies the economist's operating style, systems analysis, research operations, and decision-making analysis. This form of prospective analysis is referred to by William N. Dunn, as policy analysis. Policy analysis contains the understanding of knowledge analysis to take alternative, comparable, quantitative and qualitative policy alternatives [4]. Policy research is used in social science methods to explain phenomena. However, prospective analysis often comes from the gap between the choice of a good solution and the effort to implement it [5].

Meanwhile, retrospective policy analysis is a potential solution. The form of ex-post analysis indicates the production and transformation of knowledge after the policy has been implemented. Retrospective analysis characterizes the operating styles of several groups of analysts: First, discipline-oriented analysts. This group, consisting mostly of political, economic and sociological experts, develops and tests discipline-based theories about the causes and consequences of policies. This group does not focus on identifying policy variables that are subject to manipulation or not [6].

Second, problem-oriented analysts. This group, consisting of experts in politics, economics, and sociology who describe the causes and consequences of the policy. However, problem-oriented analysts are less concerned with the development and testing of theories that are important for the discipline of social science. This group is more focused on identifying variables that explain a problem. This group does not focus on specific objects, therefore the orientation in general, not specific [3].

Third, applications-oriented analysts. This third group consists of applied political experts, applied economists, applied sociology and applied psychology such as public administration, social work and evaluation research. This group explains the causes and consequences of policies and lack of attention to the development and testing of theories. This group is in line with the previous group that identified policy manipulation variables that could potentially achieve specific objectives that could be monitored and evaluated in order to evaluate the success of the policy [7].

Furthermore, it relates to descriptive and normative analysis, in this case, descriptive policy analysis is related to descriptive decision theory, which is related to a series of logical propositions that consistently describe or explain actions. The main purpose of this theory and framework is to explain, understand and estimate policy by identifying patterns of causality. In Figure 1, it is explained that descriptive policy analysis can be displayed as an axis that moves from the lower-left quadrant (monitoring) to the upper right quadrant (forecasting) [3].

Normative policy analysis deals with normative decision theory, which refers to a series of propositions that are logically consistent, and evaluates or determines actions. In the picture. 1, normative policy analysis is displayed as an axis that runs from the lower right quadrant (prescription) to the upper left quadrant (evaluation). Differences in knowledge needed for normative testing are distinguished from descriptive decision theories. The method for evaluating and estimating provides knowledge about policy performance and preferred policies, or policies that have been or will be optimally efficient, because the benefits outweigh the costs, or because they are optimally fair where they need them most. One of the most important things from normative policy analysis is that propositions rely on values such as efficiency, effectiveness, fairness, responsiveness, freedom, enlightenment, and security $[8]$. 
As for relating to problem structuring and problem-solving, internal and external cycles in Figs. 1, provide another important difference. Internal cycles design the problem structuring process. Problem structuring procedures are designed to identify elements to explain the problem but do not identify a solution. What are the main elements of the problem ?; Is it political, economic, social, ethical or all of this ?; How are problems structured, organized into special element configurations, such as linear sequences or a complex system ?; Who are the most important stakeholders; Who influences and is affected by the problem ?; Has the right objective been identified ?; What alternatives might make it possible to reach the goal ?; Are there any uncertain events that should be taken into account?; Did it solve the problem correctly? [3].

Instead, problem-solving methods are placed in the outer cycle in Figure 1. This method is designed to solve compared to structuring the problem. Methods such as econometric forecasting or benefit-cost analysis are problem-solving methods. This method composes questions about a number of variations from the outcomes explained by the independent variables. What is the probability to get a variant of or greater than that obtained ?; What are the benefits of policy differences?; What are the expected benefits or rewards? [3].

Integrated policy analysis links the two parts in Figure 1, the four quadrants and the internal and external cycles. The retrospective and prospective forms of analysis combine in an ongoing process. Forms of descriptive and normative analysis are also linked, as methods are designed to formulate problems and solve them. Integrated policy analysis bridges several segments of multi-disciplinary policy analysis, including legal discipline [3].

Based on the foregoing, this research is focused on evaluating the location permit policy after the implementation of licensing services is trying to be integrated electronically or known as the Online Single Submission, with the formulation of problems in the research, namely: How to evaluate the location permit policy after the implementation of licensing services seeks to be integrated electronically, both with retrospective (ex-post) analysis and prospective (ex-ante) policy analysis? [3].

\section{Research Method}

This research is normative legal research using a normative juridical approach (normative legal research). Research data is collected through library research, by collecting and analyzing various primary legal materials, secondary legal materials and tertiary legal materials that are available. Primary legal materials are basic norms or rules, basic provisions or regulations as well as statutory regulations and secondary legal materials, namely legal materials that provide further explanation of primary legal materials in the form of literature, journal articles, and also relevant research results. Data is collected by library research on books, articles, research results and legislation. Data analysis was performed descriptively qualitatively in conducting discussions on the formulation of research problems.

Descriptive data analysis was also carried out using an integrated policy analysis that links the four quadrants as presented in Figure. 1 namely monitoring, evaluation, prescription, and forecasting. The retrospective and prospective forms of analysis combine in an ongoing process. Forms of descriptive and normative analysis are also linked, as methods are designed to formulate problems and solve them. Integrated policy analysis bridges several segments of multi-disciplinary policy analysis, especially legal discipline. 


\section{Analysis}

A. Retrospective (Ex-Post) Analysis of the Location Permit Policy After OSS Implementation

In order to accelerate and increase investment and try to be more effective and efficient, the Government issued GR No. 24/2018. Based on Article 43 paragraph (1) GR No. 24/2018, further provisions regarding location permits are governed by ministerial regulations that carry out government affairs in the agrarian sector. Article 43 Paragraph (2) further confirms that the Ministerial Regulation as referred to in paragraph (1) is issued no later than 15 (fifteen) days after GR No. 24/2018 is promulgated. Therefore, 15 (fifteen) days after June 21, 2018, namely July 13, 2018, the government is obliged to issue implementing regulations (Ministerial Regulations) mandated by Article 43 GR No. 24/2018.

On July 13, 2018, the Government promulgated two Ministerial Regulations as the implementation of Article 43 GR No. 24 of 2018, namely (1) Regulation of the Minister of Agrarian Affairs and Spatial Planning/Head of the National Land Agency Number 14 of 2018 on Location Permits; and (2) Regulation of the Minister of Agrarian Affairs and Spatial Planning/Head of National Land Agency Number 15 of 2018 on Technical Considerations on Land.

ATR/BPN Ministerial Regulation No. 14 of 2018 and ATR/BPN Ministerial Regulation No. 15 of 2018 as well as revoking and declaring the Minister of Agrarian Affairs and Spatial Planning/Head of National Land Agency Number 5 of 2015 on Location Permits as amended by Regulation of the Minister of Agrarian Affairs and Spatial Planning/Head of National Land Agency Number 19 of 2017 on Amendment to the Regulation of the Minister of Agrarian Affairs and Spatial Planning/Head of National Land Agency Number 5 of 2015 on Location Permits, also Regulation of Head of National Land Agency Number 2 of 2011 on Guidelines for Technical Considerations in Land Issuance Location Permit, Location Determination and Permit Changes in Land Use and Regulation of the Head of National Land Agency Number 1 of 2010 on Standards and Regulation of Land Services and Regulation of the Minister of Agrarian and Spatial Planning/Head of National Land Agency Number 4 of 2017 on Service Standards of the Ministry of Agrarian and Spatial Planning/National Land Agency.

The regulation of location permits and land technical considerations regulated by Permen ATR / BPN Number 14 of 2018 and ATR / BPN Number 15 of 2018 are carried out to support the acceleration of licensing by electronic or OSS integration. In connection with OSS, business licenses issued by OSS institutions which are non-ministerial government institutions that carry out governance affairs in the field of investment for and on behalf of the Minister, Governor, Regent / Mayor to businesses through an integrated electronic system. For business operators who need infrastructure but do not yet have or master infrastructure, a Business License is issued after the OSS institution issues:

(1) Location Permit;

(2) Aquatic Location Permit;

(3) Environmental Permit;

(4) Building Construction Permit (IMB)

Location permit according to Article 1 number ATR / BPR Permen Number 14 of 2018 is a license granted to a business actor to obtain land needed for his business and/or activities and also applies as a permit to transfer rights and to use the land for business purposes and/or its activities. Business actors referred to in this case are individuals or non-individuals who carry out business and/or activities in certain fields. Individual business actors are individual 
Indonesian residents who are capable of acting and doing legal actions. While nonindividual business actors consist of: limited liability companies, public companies, regional public companies, other legal entities owned by the state, public service bodies, broadcasting institutions, business entities established by foundations or cooperatives.

Location permits are divided into (a) location permits based on commitments and (b) location permits without commitment. Business actors who do not need infrastructure or have mastered or have the infrastructure for business activities do not need location permits, for example online business ventures, retail traders, businesses located in commercial activity centers, and so on. Commitment, in this case, is a statement of a business actor to fulfill the requirements of business permit and / or commercial or operational permit. Commitments that must be fulfilled for location permits based on commitments are Land Technical Considerations and Local Government approval.

Location permits based on commitments and without commitments are processed based on ATR/BPN Ministerial Regulation Number 14 of 2018 on Location Permit and ATR/BPN Ministerial Regulation Number 15 of 2018 on Land Technical Considerations. Location permits based on Commitments are issued by first including the Statement of Fulfillment of Location Permit Commitments. After the Commitment Based Location Permit is issued, Business actors who do not submit the requirements within ten days will cancel the location permit, otherwise, if the business actor meets the requirements within 10 days, the effective location permit will be effective.

Business actors whose business location land meets seven criteria, namely: according to the RDTR, there is already a location permit, a certain authority or development area, business expansion, area limits and a national strategic project through an OSS institution obtaining a location permit without commitment, so that the effective location permit applies and the Office Land provides technical considerations of land within ten days, then businesses can use and utilize land. Thus there are differences in governance between location permits based on commitment and without commitment.

ATR / BPN Regulation No. 14 of 2018 states that location permits are granted for a period of 3 (three) years from the effective date of location permits. The acquisition of land by the location permit holder must be completed within the period of the location permit. If within the period of time the location permit for land acquisition has not been completed, then: (1) The location permit can be extended for 1 (one) year, if the acquired land reaches $50 \%$ (fifty percent) or more than the area of land designated in the permit location; (2) Location permit cannot be extended if the period of location permit referred to in paragraph (1) ends and the acquisition of land is less than $50 \%$ (fifty percent) of the land area designated in the location permit. Thus the location permit holder is required to have a location permit holder must report periodically every three months to the Head of the Land Office regarding land acquisition that has been carried out based on the location permit and the implementation of the land use. Land that has been acquired must be registered with the local Land Office no later than one year after the expiration of the location permit.

The monitoring and evaluation activities are carried out in stages by the Regional Office and the Land Office for (a) land acquisition; (b) land use and use; and (c) security carried out by business actors for the land that has been obtained. The results of monitoring and evaluation are taken into consideration when canceling a location permit.

Table. 2 Comparison between ATR/BPN Ministerial Regulation Number 5 of 2015 jo ATR/BPN Ministerial Regulation Number 19 of 2017 and ATR/BPN Ministerial Regulation Number 14 of 2018 regarding Location Permit, showing a comparison between current and previous regulations in the retrospective (ex-post) analysis frame 
Table. 2 Comparison between ATR/BPN Ministerial Regulation Number 5 of 2015 jo ATR/BPN Ministerial Regulation Number 19 of 2017 and ATR/BPN Ministerial Regulation Number 14 of 2018 on Location Permit

\begin{tabular}{|c|c|c|c|}
\hline No. & Description & $\begin{array}{c}\text { ATR/BPN Ministerial } \\
\text { Regulation Number } 5 \text { of } \\
2015 \text { jo ATR/BPN } \\
\text { Ministerial Regulation } \\
\text { Number } 19 \text { of } 2017\end{array}$ & $\begin{array}{c}\text { ATR/BPN Ministerial Regulation } \\
\text { Number } 14 \\
\text { of } 2018\end{array}$ \\
\hline 1. & $\begin{array}{c}\text { Subject } \\
\text { Requirements }\end{array}$ & $\begin{array}{l}\text { Does not require a } \\
\text { business registration } \\
\text { number (NIB) }\end{array}$ & Requires NIB \\
\hline 2. & $\begin{array}{l}\text { Apllication } \\
\text { Mechanism }\end{array}$ & $\begin{array}{l}\text { Applicants come directly } \\
\text { to the One Stop } \\
\text { Integrated Services Office } \\
\text { (PTSP) }\end{array}$ & Through the OSS system \\
\hline 3. & $\begin{array}{l}\text { Designation of } \\
\text { the requested } \\
\text { location }\end{array}$ & $\begin{array}{l}\text { Map of the location } \\
\text { pointer }\end{array}$ & $\begin{array}{l}\text { Through the OSS portal: } \\
\text { coordinates or onscreen } \\
\text { - If a digital RDTR is available, } \\
\text { location permits are issued } \\
\text { automatically. } \\
\text { If there is no RDTR yet then } \\
\text { the location permit is given } \\
\text { with commitment }\end{array}$ \\
\hline 4. & $\begin{array}{c}\text { Location } \\
\text { permit issuer }\end{array}$ & DPMPTSP/Regent/Mayor & OSS Institution \\
\hline 5. & $\begin{array}{l}\text { Signing } \\
\text { location } \\
\text { permits }\end{array}$ & $\begin{array}{c}\text { Head of } \\
\text { DPMPTSP/Regent/Mayor }\end{array}$ & $\begin{array}{l}\text { Head of OSS Institution } \\
\text { electronically }\end{array}$ \\
\hline 6. & $\begin{array}{l}\text { Location } \\
\text { Permit } \\
\text { Document }\end{array}$ & Shaped analog/paper & $\begin{array}{l}\text { In electronic form that can be } \\
\text { printed }\end{array}$ \\
\hline 7. & $\begin{array}{l}\text { Position } \\
\text { Technical } \\
\text { Considerations } \\
\text { Land }\end{array}$ & $\begin{array}{l}\text { Before the location } \\
\text { permit is issued }\end{array}$ & $\begin{array}{l}\text { - After location permits are } \\
\text { issued based on commitment } \\
\text { or without commitment } \\
\text { Technical Considerations } \\
\text { Land as a basis for location } \\
\text { permits is effective }\end{array}$ \\
\hline 8. & $\begin{array}{l}\text { Business } \\
\text { permit } \\
\text { position }\end{array}$ & $\begin{array}{l}\text { As a location permit } \\
\text { requirement }\end{array}$ & $\begin{array}{l}\text { Business license issued after } \\
\text { location permit is available }\end{array}$ \\
\hline 9. & $\begin{array}{l}\text { Deadline for } \\
\quad \text { land } \\
\text { registration }\end{array}$ & Unregulated & $\begin{array}{l}\text { Obliged to register land acquired } \\
\text { no later than one year after the } \\
\text { expiration of the location permit } \\
\text { (Article 23) }\end{array}$ \\
\hline
\end{tabular}




\begin{tabular}{|c|c|c|c|}
\hline No. & Description & $\begin{array}{c}\text { ATR/BPN Ministerial } \\
\text { Regulation Number 5 of } \\
\text { 2015 jo ATR/BPN } \\
\text { Ministerial Regulation } \\
\text { Number 19 of 2017 }\end{array}$ & $\begin{array}{c}\text { ATR/BPN Ministerial Regulation } \\
\text { Number 14 } \\
\text { of 2018 }\end{array}$ \\
\hline 10. & Legal force & $\begin{array}{c}\text { Technical Considerations } \\
\text { on Land as a } \\
\text { consideration of the } \\
\text { Regional Government in } \\
\text { issuing location permits }\end{array}$ & $\begin{array}{c}\text { Technical considerations on land } \\
\text { as a determinant of validity or } \\
\text { refusal of location permits (Article } \\
15)\end{array}$ \\
$\begin{array}{c}\text { Local governments approve or } \\
\text { reject location permits based on } \\
\text { Land Technical Considerations }\end{array}$ \\
\hline
\end{tabular}

Source: Directorate General of Agrarian Structuring, Ministry of Agrarian Affairs and Spatial Planning / National Land Agency, August 2018.

B. Prospective (Ex-Ante) Analysis of the Location Permit Policy After The Implementation of the Integrated Electronic Business Licensing Services

The challenge faced in the implementation of OSS is the unavailability of a Spatial Detail Plan (RDTR). The acceleration of RDTR preparation is done to support the implementation of OSS. The RDTR is intended as a basis for spatial use licensing, as stated in Law Number 26 of 2007 on Spatial Planning. At present only a few regencies and cities have RDTR. Thus, the acceleration of the RDTR will be implemented in 100 to 140 city districts out of a total of 250 second-level regions, where $80-90$ percent of investment is concentrated in it.

Furthermore, technological developments vary between regions, making the application of location permits and land technical considerations rather difficult in regions that are difficult to gain access to Information Technology. Another challenge is that OSS has not been implemented in all regions in Indonesia.

One map policy acceleration (synchronization with one map policy) with map synchronization in Indonesia becomes a strategic policy that benefits, especially if Indonesia enters E-Government in government activities. Furthermore, through Presidential Regulation Number 39 of 2019 on One Indonesian Data, it is hoped that spatial data can accelerate the granting of location permits and technical considerations on land without commitment, which can accelerate business licensing business processes in Indonesia, in the context of increasing Indonesia's competitiveness.

\section{Conclusions}

Based on the foregoing it can be concluded that with the Ministerial of Agrarian Affairs and Spatial Planning/Head of the National Land Agency (ATR/BPN) Regulation there is a difference between the regulation of location permits before and after the implementation of OSS, through ATR/BPN Ministerial Regulation Number 14 of 2018 regarding Location Permit. In this case, the OSS Institution becomes the institution that issues location permits, which were previously issued by the Regent/Mayor, Governor, and Minister in accordance with their authority (ex-post). The procedure for issuance is also easier with shorter 
completion time and creates legal certainty for business actors because businesses can utilize OSS services to process location permits both with commitment and without commitment. Meanwhile prospectively (ex- ante) this has encouraged accelerated business licensing, and synchronized spatial planning and spatial use, supported by one map policy and one Indonesian data.

Recommendations or future policy directions recommended in this paper are important to coordinate among various stakeholders (stakeholders) in the application of location permits after OSS implementation. Of course this can support land reform in Indonesia, and of course, create legal certainty and investment certainty in Indonesia.

\section{References}

[1] OECD, ,Ringkasan Eksekutif Kajian OECD mengenai Reformasi Regulasi Indonesia Memperkuat Koordinasi dan Menghubungkan Pasar,“ [Online]. Available: https://www.oecd.org/gov/regulatorypolicy/executive $\% 20$ summary\%20INDO $\% 20$ with\%20cover\%20for\%20Internet.pdf . [Cit. 17 August 2019].

[2] The World Bank, „Doing Business Measuring Business Regulations,“ [Online]. Available: https://www.doingbusiness.org/ . [Cit. 17 August 2019].

[3] W. N. Dunn, Public Policy Analysis An Integrated Approach, New York: Routledge, 2018.

[4] W. Williams, Social Policy Research and Analysis: The Experience in the Federal Social Agencies, New York: American Elsevier, 1971.

[5] G. T. Allison, Essence of Decision: Explaining the Cuban Missile Crisis, Boston, MA: Little, Brown, 1971.

[6] J. C. Coleman, Problems of Conceptualization and Measurement in Studying Policy Impact, K. M. Dolbeare, Ed., Beverly Hills and London: Sage Publications, 1975.

[7] T. D. Cook a D. T. Campbell, Quasi-Experimentation: Design and Analysis Issues for Field Settings, Boston, MA: Houghton Mifflin, 1979.

[8] H. D. Lasswell a A. Kaplan, Power and Society: A Framework for Political Inquiry, New Haven, CT: Yale University Press, 1950. 